\title{
QUALITATIVE RESEARCH IN MANAGEMENT AND ORGANISATIONAL STUDIES WITH REFERENCE TO RECENT SOUTH AFRICAN RESEARCH
}

\author{
WILLEM J SCHURINK \\ Guest Editor \\ Social Science Research Consultancy
}

\begin{abstract}
This introduction to this special edition of the Journal dealing with recent qualitative work undertaken by local industrial psychologists, sketch the nature of qualitative research globally, its position in South Africa, and finally, the status of such research as applied to the management/organisational field abroad as well as in South Africa. From this and the other articles it is clear that qualitative research is healthy in management related areas in South Africa, but that local scholars have work on their hands to train promising researchers in this research style in order to sustain it and developing it further.
\end{abstract}

\section{OPSOMMING}

Hierdie inleiding tot die spesiale uitgawe van die Tydskrif vir Menslikehulpbronbestuur wat handel oor kwalitatiewe studies wat deur plaaslike bedryfsielkundiges onderneem is, skets die aard van globale kwalitatiewe navorsing, die stand van die tipe navorsing in Suid-Afrika, en, ten slotte, die stand van hierdie tipe navorsing in die bestuurs-/organisasieveld in sowel die buiteland as plaaslik.Vanuit hierdie artikel en die ander bydraes is dit duidelik dat kwalitatiewe navorsing organisasie verwante areas in Suid-Afrika gesond is maar dat werk op plaaslike geleerdes wag om belowende navorsers in hierdie navorsingstyl op te lei ten einde dit te handhaaf en verder te ontwikkel.

Denzin and Lincoln (1998), two renowned scholars in qualitative research, are correct when they point out that a quiet methodological revolution has been taking place in the social sciences and humanities, resulting not only in a blurring of disciplinary boundaries but also in the mutual focus on an interpretive, qualitative approach to research and theory. Qualitative research has a long and distinguished history in the intellectual enterprise. Well known is the pioneer work in sociology undertaken by the "Chicago school" in the 1920s and 1930s during which the importance of qualitative research for the study of human group life was established. In anthropology, during the same period, the path-breaking studies of Boas, Mead, Benedict, Bateson, EvansPritchard, Radcliffe-Brown and Malinowski outlined the execution of the fieldwork method, wherein the researcher/observer went to a foreign setting to study the customs and habits of another society and culture (cf. Denzin \& Lincoln 1998). Qualitative research soon invaded other social disciplines. The extent of this invasion of the social sciences and its related professional fields, and the host of textbooks, journals, Web sites, international conferences, research monographs and readers that have consequently been published in the mid-1970s are nothing but remarkable! Among the professional areas that have thus far responded enthusiastically to qualitative methods and theory are: anthropology, sociology, education, psychology, criminology and criminal justice, social work, health, human development, family studies, communications, information studies, gerontology, industrial psychology and organisational and management studies. Merriam and associates (2002: xv) are correct when they conclude: "... qualitative research is an accepted methodology in all the social sciences and applied fields of practice".

In this special edition of the Journal of Industrial Psychology that is devoted to qualitative studies undertaken by local industrial psychologists and other colleagues working in the management and organisational fields, it seems appropriate, if not necessary, (i) to take a brief look at the nature of qualitative research abroad, (ii) to take stock of the state of the art in South Africa, and (iii) to obtain a sense of the status of qualitative research in the management and organisational field as well as South Africans' approach to qualitative research in these two areas.

Requests for copies should be addressed to: W Shurink, Department of Human Resource Management, RAU University, PO Box 524, Auckland Park, 2006
While this is a pleasant task, qualitative research's longdistinguished history, the divergent disciplines, philosophies, theories and traditions that contributed to this research style over a century, and the current key issues, like its "double crisis", namely the inclusion of the Other and the legitimation of the field, make this a demanding undertaking. However, a few cautionary words are in order. First, in tackling these three tasks, it must be cautioned that the article can at best scratch the surface, resulting in a discussion that is far from exhaustive, and represents, in the final analysis, an incomplete discussion that at would best pave the way for hopefully more discussions of qualitative-related issues to appear in subsequent issues of the Journal. Second, while reference will inevitably be made to more philosophical dimensions of social research such as ontology and epistemology, the emphasis will be on methodology ${ }^{1}$. Finally, although, methodological issues will be addressed, because of the constraints of an introductory article, it is not possible to deal with methodical and technical matters, such as data collection, and data analysis here ${ }^{2}$.

\section{INTERNATIONAL QUALITATIVE STUDIES: SOME BRIEF OBSERVATIONS}

A brief overview of the literature on qualitative research reveals among others, as already indicated, (i) an increase in social science attention to qualitative research and its associated terms particularly over the past three decades, which has been exceptional since it resulted in a large variety of books and journals on qualitative research; and (ii) which has grown out of a wide range of intellectual and disciplinary traditions, resulting in its contemporary adherents not using a unified set of philosophies or methods. Not unexpected, these developments have resulted in contemporary scholars not reaching consensus on what qualitative studies entail. In fact, "qualitative research" means different things to different people. While this state of affairs has surely complicated researchers' decision to choose qualitative methods when embarking upon research, it has not prevented them from utilising these methods. But what are the key assumptions and characteristics of these studies? I will now briefly discuss core aspects of this type of research.

1 Readers interested in these and other dimensions need to consult the various excellent works that are available (cf. in management research and excellent epistemological source is Johnson and Duberley's Understanding management research. An introduction to epistemology (2000), dimensions of qualitive research).

2 A number of excellent textbooks dealing with specific decision taking steps in research generally and organisational qualitive specifically are available (regarding management research methods, recent examples are: Gill and Johnson (2002), Lee (1999), Gummesson, (2000), Symbol and Cassell (1998). 
Explaining qualitative research

Although sharing an anti-positivistic set of basic beliefs or paradigms $^{3}$, qualitative researchers hold different perspectives, based on their worldviews, particularly with regard to ontology and epistemology, i.e. what should be researched and what scientific truth entails. This implies that the term "qualitative research" means different things to different people (cf. Strauss \& Corbin, 1990). Hence, it is difficult to describe qualitative research in a way that will satisfy everybody. The following views of two prominent scholars illustrate some of the differences as well as key commonalities of qualitative research:

- "[Q]ualitative research is: (i) grounded in a philosophical position which is broadly interpretivist in the sense that it is concerned with how the social world is interpreted, understood, experienced or produced. Whilst different versions of qualitative research might understand or approach these elements in different ways (for example, focusing on social meanings, or interpretations, or practices, or discourses, or processes, or constructions) all will see at least some of these as meaningful elements in a complex possibly multi-layered - social world; (ii) based on methods of data generation which are flexible and sensitive to the social context in which data are produced (rather than rigidly standardized or structured, or removed from 'real life' or 'natural' social context, as in some forms of experimental method); and (iii) based on methods of analysis and explanation building which involve understandings of complexity, detail and context. Qualitative research aims to produce rounded understandings on the basis of rich, contextual, and detailed data. There is more emphasis on 'holistic' forms of analysis and explanation in this sense, than on charting surface patterns, trends and correlations. Qualitative research usually does use some form of quantification, but statistical forms of analysis are not seen as central" (Mason 1996, p. 4).

- "We use qualitative research as an umbrella term to refer to several research strategies that share certain characteristics. The data collected have been termed soft, that is, rich in description of people, places, and conversations, and not easily handed by statistical procedures. Research questions are not framed by operationalizing variables; rather, they are formulated to investigate topics in all their complexity, in context. While people conducting qualitative research may develop a focus as they collect data, they do not approach the research with specific questions to answer or hypotheses to test. They also are concerned with understanding behavior from the subject's own frame of reference. External causes are of secondary importance. They tend to collect their data through sustained contact with people in settings where subjects normally spend their time - classrooms, cafeterias, teacher's lounges, dormitories, street corners" (Bogdan \& Biklen, 1998, p. 2).

Some of the differences and commonalities are also reflected in the concepts and terms found in the field of qualitative research, as shown by the ensuing discussion.

\section{Terms used for qualitative research}

Qualitative research is, as John and Lyn Lofland (1984) note, a "many-labelled tradition". The most commonly used labels appear to be "field research"/"fieldwork", "naturalism", "ethnography", "interpretative research" and "constructivist research".

"Field research" or "fieldwork" is typically used by anthropologists and derives its use from "the fact that data tend to be collected in the field as opposed to laboratories or other researcher-controlled situations" (Bogdan \& Biklen, 1998, p. 3).

"Naturalism" or "naturalistic research" implies the minimising of the presuppositions with which the researcher approaches the phenomenon under study as well as a close and searching description of the mundane details of everyday life (Lofland \&
Lofland, 1984, p. 3). Researchers typically frequent places where the events they are interested in occur naturally. Data is gathered in the course of natural behaviour such as talking, visiting, looking, walking, working, eating, etc.

The term "ethnographic" is applied to qualitative research as well. Some scholars use the term in a formal sense to refer to a particular variant of qualitative research. Others use it more generally and equate it to qualitative research, particularly when doing qualitative research of a predominantly descriptive nature.

The term "interpretative" refers, according to Mouton (1986, p. 2), to the fact that qualitative research is not aimed at explaining human behaviour in terms of universally valid laws or generalisations, but rather at understanding and interpreting the meanings and intentions that underlie everyday human action.

"Constructivism", just as "interpretivism", relates to the theory of meaning (hermeneutics). However, constructivism breaks away from the assumption that reality can be understood by interpreting the meanings that people in a specific setting attach to it. To constructivists, reality is relative and the construction of the life worlds of subjects can never reflect the true picture. Findings are actually created through interaction between the researcher and the subject.

Finally, the term "qualitative research", probably the most general, encompassing and widely accepted term, is an indication that this approach concentrates on the qualities of human behaviour, i.e. on qualitative aspects and not quantitatively measurable aspects of human behaviour (Mouton, 1986, p. 2). Bogdan and Biklen (1998, p. ix) write that in the early 1970s, "qualitative research" broke out of the boundaries of anthropology and sociology and "came on the scene as a crossover designation for field research people not weeded to a particular discipline ... Not belonging to any one tradition, the phrase heralded twenty years of increased influence, development, and cross-fertilization. While some in the traditional disciplines resisted the use of the term, for most it united the old timers with those who are new to the approach".

At this juncture, it is important to emphasise what has been suggested in the preceding is that "qualitative research" has seen many changes during especially the last thirteen years, which has resulted in the field becoming much more diverse and "challenging", if not, reflecting controversy and turmoil. Bogdan and Biklen (1998, p. x) describe this vividly:

"While "qualitative research" gave affiliation to people in the 1970s and 1980s, in the 1990s shifts in the field began pulling adherents apart. The approach has attracted many who were trained in a more quantitative approach to research. They have championed a brand of qualitative research which is more structured and systematized than earlier methods, an approach which emphasizes qualitative technique more than a qualitative way of thinking. At the same time, other qualitative researchers were attracted by scholarship in the humanities which emphasised postmodern approaches to enquiry. These researchers deemphasized the careful collection of field data and concentrated more on research as representation through writing, and on the politics of research."

Taking the early 1900s as the early stages of qualitative research, Denzin and Lincoln (2000) distinguish between six moments to describe its history. Since these stages of qualitative development provide a good explanation of how the field became diverse and controversial, it is useful to take a closer look at them.

3 A paradigm is a set of beliefs that constitutes the researcher's ontology (i.e. the researcher's perceptions regarding the nature of reality/the world and what there is to know about it); epistemology (i.e. the researcher's perceptions of where s/he stands in relation to reality/the world); and methodology (the researcher's perception of how s/he can find out about reality/the social world) 


\section{A brief historical account of developments in} qualitative research

By now it should be clear that qualitative research as a field of enquiry in its own right crosscuts disciplines, fields and subject matters, and there is a complex, interconnected family of terms, concepts and assumptions surrounding the term qualitative research. These conditions and beliefs include the traditions associated with positivism, post-structuralism and the many qualitative research perspectives or methods, connected to cultural and interpretive studies. These features of qualitative research, according to Denzin and Lincoln (2000), operate in a complex historical field that crosscuts six historical moments, which simultaneously operate in the present. Hatch (1997) points out that the assumptions raised from within these moments have crystallized into three paradigms of enquiry: the modernist, the interpretive and the postmodernist.

The six moments can be summarized as follows:

- Traditional period (1900 to the 1940s). Researchers such as Malinowski, Margaret Mead and Radcliffe-Brown employed ethnography, phenomenology or ethnomethodology to study human phenomena. These strategies are characterised by observation (participant observation) and a description of the actions of a small number of subjects and the meanings that they attach to their actions.

Data analysis is mainly interpretative, involving descriptions of the phenomena. The main aim is to write objective accounts of lived experiences (fieldwork experiences). This notion of objectivity has however fallen into disrepute because ethnographers in particular have been accused of complying with imperialism, and their works have come to be seen as relics of the colonial past. However, in order to solve the qualitative researcher's problems regarding objectivity and representation of subjects, proponents of phenomenology and ethnomethodology recently broadened their field of interest by linking lived experience with social context.

- The modernist phase (the 1940s to the 1970s). The modernist phase was built on the works of the traditional period, social realism and naturalism. This phase is characterised by the interpretation of reality by means of formalised qualitative methods and the undertaking of rigorous data analysis (e.g. analytical induction and grounded theory). Examples of this perspective (which still prevails in recent studies) include the symbolic interactionist perspective as reflected in the works of Bogdan and Taylor (1975), Glaser and Strauss (1967) and Lofland (1971).

Between the 1940s and the 1970s, the modernist approach included phenomenology, ethnography, symbolic interactionism, critical theory, and applied and action research. Strategies of enquiry ranged from grounded theory and the case study to the methods of historical, biographical, ethnographic and clinical research. Methods of data collection varied from interviewing and participant observation to the study of human documents. Data was analysed by means of analytical induction and grounded theory.

- Blurred genres (1970 to 1986). Critics of the modernist phase argued that it is impossible for qualitative researchers to discover the real world, as the people living in it know it. Qualitative studies are thus the researcher's interpretations of the subject's experiences. What we take to be objective knowledge and truth is the result of a particular perspective. Knowledge and truth are thus constructed and not discovered by the mind. Critical theory, including neo-positivism, neomarxism, materialism and participatory enquiry, was developed during this period of blurred genres.

- Crisis of representation (the mid-1980s). New models of truth and method that would best describe and interpret the experiences of other people and settings were continually being sought in the mid-1980s. The basic assumption in this period was that the researcher cannot be objective and value free and that rigorous studies of social processes (such as advocated by symbolic interactionism) are impossible. This assumption demanded a serious rethinking of concepts such as validity, reliability and generalisability. Issues such as class, gender, race and values were also pertinent. The research process therefore had to become more reflective and fieldwork and writing had to converge. Researchers and subjects thus became partners in the research process. This perspective has given rise to cultural studies as well as feminist and action research.

- The fifth moment (the 1990s). This phase is defined and shaped by the assumption that qualitative researchers cannot directly capture lived experience. Data should therefore not be interpreted or analysed. The researcher should rather gather and present data in such a way that the subjects speak for themselves (Strauss \& Corbin, 1990, p. 21). Lived experience cannot be created in the social text written by the researcher. Theories are therefore written in narrative terms as tales of the field. Researchers remain preoccupied with the representation of the Other and the question of how to develop a social science that includes the Other. When analysing the development of the qualitative research paradigm, the move to include the Other in a larger research process is evident. However, the question of how the Other could be included has not been solved.

This trend in qualitative research, namely to become more "messy", requires serious rethinking in terms of scientific validity and reliability. As neither the issue of representation nor the issue of legitimation has been solved, a double crisis is presently confronting qualitative researchers (Denzin \& Lincoln, 1994). The question is whether the truth can ever be captured and represented by means of qualitative research, because even if the Other is empowered to become a researcher, differences in power, knowledge etc. remain part of the relationship between researchers and subjects. The final product will still be that of a researcher and not that of the subjects. Therefore, uncontaminated truth cannot be established. After all, the researcher, even by not positioning him/herself, does not relate to reality in the same way as his/her research subjects. It is clear that in order to solve this crisis of legitimation, qualitative researchers need to develop new criteria that allow them and their readers to make a connection between the text and the real world written about.

The Other should be empowered to undertake their own historical or social investigations, or researchers should engage together with the Other in "narrative adventures" and "experimental" or "messy" texts. The researcher is therefore merely the link between the field text and the community. $\mathrm{S} /$ he empowers the Other to become a co-researcher who will speak for him/herself.

In their later discussion of the qualitative phases, Denzin and Lincoln (2000) talk of "a triple crises of representation, legitimation, and praxis" "in which the inevitably creative and interpretive nature of qualitative writing is put under the microscope, including the perspective of the qualitative writer, and searching questions are raised about how to evaluate the quality of qualitative research and evaluation" (Patton, 2002, p. 79-80).

- The sixth moment or "postexperimental" phase. Here qualitative research's boundaries are expanded in order to accommodate creative non-fiction, autobiographical ethnography, poetic representations and multimedia presentations.

The brief overview of these six phases in qualitative research development will suffice. Regardless of the possibility of more moments developing in future, it is clear that qualitative research should be seen as a discipline reflecting many interesting varieties. Let's take a closer look at some of these.

\section{Types of qualitative research}

Qualitative research is found in virtually all recognised social science disciplines and study areas (cf. Patton 2002; Merriam 2002), and therefore it should come as no surprise to find that 
different disciplines and fields have drawn on, and contributed to, qualitative research differently. These diverse terminologies, strategies and procedures have confused particularly newcomers to qualitative enquiry and have led to the realisation that there is presently no consensus on how to classify qualitative research. Examples of the diverse ways in which scholars writing on qualitative texts have organised qualitative research are:

(a) Jacob (1987) distinguishes between ecological psychology, holistic ethnography, ethnomethodology of communication, cognitive anthropology and symbolic interactionism.

(b) Crotty (1998) draws a distinction between positivism (and postpositivism), interpretivism (including phenomenology, hermeneutics, and symbolic interactionism), critical enquiry, feminism and postmodernism.

(c) Creswell (1998) identifies the following five "traditions": biography, phenomenology, grounded theory, ethnography and case study.

(d) Bogdan and Biklen (1998), in their textbook on qualitative research for education, emphasize the phenomenological perspective and differentiate between phenomenology, symbolic interaction, culture, ethnomethodology, and cultural studies, feminisms, post modernism, and critical theory.

(e) Tesch (1990) listing 45 approaches, divides them into designs (e.g. case study), data analysis techniques (e.g. discourse analysis), and disciplinary orientation (e.g. ethnography).

(f) Denzin and Lincoln (2000) identified the following research strategies: case study, ethnography, phenomenology, grounded theory, biographical, historical, participatory and clinical.

(g) Merriam (2002). Using the more commonly used approaches to doing qualitative research, she distinguishes between: basic interpretive, phenomenology, grounded theory, case study, ethnography, narrative analysis, critical and postmodern-poststructural approaches.

(h) Patton (2002) distinguishes between the following 16 varieties of qualitative enquiry: ethnography, reality testing (e.g. positivist and reality approaches), constructionism/ constructivism, phenomenology, heuristic enquiry, ethnomethodology, symbolic interactionism, semiotics, hermeneutics, narratology/narrative analysis, ecological psychology, systems theory, chaos theory (e.g. non-linear dynamics), grounded theory and orientational (feminist enquiry, critical theory, and queer theory).

When one takes a closer look at these classification attempts of traditions and approaches to qualitative enquiry, one is bound to conclude that the field is currently rather confusing. Even seasoned researchers using this style of research, like Miles and Huberman (1994 p. 5), find qualitative enquiry rather bewildering: "As comprehensive and clarifying as these catalogs and taxonomies may be, they turn out to be basically incommensurate, both in the way different qualitative strands are defined and in the criteria used to distinguish them. The mind boggles in trying to get from one to another".

The preceding brief overview of the field of qualitative research will have to suffice since this survey should now be supplemented by an outline of the state of the art in South Africa.

\section{QUALITATIVE RESEARCH IN SOUTH AFRICA: BRIEF OBSERVATIONS ON ITS CURRENT STATUS}

As far as could be established, there is no systematic historical analysis of qualitative studies in South African. A synoptic study of the local literature clearly reveals that while this research style has been institutionalized at certain South African universities, most notably sociology, psychology and education, and at certain centres and organisations, this is certainly not widespread (cf. Mouton \& Muller, 1998).
According to Mouton and Muller (1998), who include qualitative studies in their "Tracking trends in theory and method: past and future", ethnographic studies, participant observation, unstructured interviewing methods and the use of documentary sources have enjoyed, a long tradition especially in anthropological (cf. scholars such as Wilson, Kuper, RadcliffBrown, Hammond-Tooke, Preston-Whyte, Boonzaaier, Sharp, Kotze, Gordon, and Thornton) and historical studies (cf. Bozzoli, 1990) in South Africa.

These scholars (Mouton \& Muller 1998) seem to be correct in stating that as one moves outside South African anthropology and history, examples of qualitative empirical studies become harder to find. While this might be the case, there is no doubt that many local qualitative studies have been undertaken rather sporadically and are quite diverse.

From my reading of Mouton and Muller's (1998) and some other recent local methodological textbooks (cf. Terre Blanche \& Durrheim, 1999, Mouton, et al. 1998, De Vos, 1998) the following inferences seems reasonable:

- A significant non-positivistic tradition is found in psychology in Kruger's and other's phenomenological work (cf. Kruger, 1988, Stones, 1988, Van Vuuren, 1991), resembling the Duquesne tradition in the USA (see the work of Giorgi, 1997), and which is based on the European phenomenology of Husserl and Van den Berg.

- Incidentally local qualitative work is quite similar to that of the modernist paradigm and especially to the extent that South African researchers make use of the "real" world in informing and shaping their theorizing. The following work provides good examples of these studies: Crause and Botha's (1977) study of prostitutes and deviants in Port Elizabeth's harbour area ${ }^{4}$; Schurink's (1979) unstructured interview studies of various deviant and criminal worlds in a north eastern community of Pretoria, Schurink and co-workers' work on sex workers and other sex industry participants in a number of South African cities (cf. Schurink, 1985, Schurink \& Winterbach, 1979; Minnaar, Venter \& Schurink, 1980; Schurink \& Levinthal; 1983; Schurink \& Ndabandaba, 1991; Schurink, Liebenberg \& Schurink, 1993); Marais' (1989) study of the relationship between the living context of a group of local liberation theologians and their interpretation of the Bible; Schurinks' (1990a) participant observant study of a 1970s Pretoria gay club; Schurink's studies of biographical sketches of homosexual women and men $(1981 ; 1989)$, Lötter and Schurink's (1984) study of prison gangs; Ferreria's (1988) sociological analysis of medical encounters of aged people at an outpatient centre, Engelbrecht's (1991) study of Johannesburg bomb victims, Trollip's (1991) study of the meaning particular women in a Ndyundya-Ndebele kinship group attached to acculturated clothing practices; Steenkamp's (1991) situation analysis of swimming-pool managers at local authorities; Graser's (1992a \& 1992b) research into family murder; Ferreira's (1992) qualitative investigation of the emotional experiences of South African divorced men; Schurink, et al.'s (1992) family murder research; Schurink's (1994) study of prison managers' views on the 1994 election and prison violence; Maree's (1995 \& 1996) criminological inspection of bankrobbers; Schurink, Molope \& Tshabalala's (1997) study of child labour; Nomoyi and Schurink's (1998) study of insider accounts of necklacing in three Port Elizabeth townships; and Roos et al's (2002) study of final-year medical students' social construction/ experiences of 'soft skills' in the 'old' MBChB curriculum of the University of Pretoria.

- The phenomenon of an increasingly wide variety of local qualitative studies that utilize different methods and traditions of such research. Examples here are: Danziger (1963); Meyer and Pinto (1982); Pretorius (1984); Mouton (1983, 1985 \& 1986); Siwani (1986); Graham and Zungu 
(1987); Levett (1998 \& 1990); Siwani, et al. (1990), Mazibuko (1990); Lindegger and Bosman (1990); Berger (1990); Davidoff and Van den Berg (1990); McNaught and Raubenheimer (1991); Ballen et al. (1991); Steyn (1992); Potter and Moodie (1992); MacDonald, (1993); Ramphele (1993); Van Zyl (1993); Oliphant (1993); Van Vlaenderen and Gilbert (1993); Walker (1994); Butchart, et al. (1994); Sliep (1994); Maconachie, et al.(1993); Dixon, et al. (1994); Cleaver and Pallourios (1994); Kaminer \& Dixon (1995); Modungwa (1995); Shantall (1995); Duncan (1996); Ashley et al. (1996); Swartz (1995 \& 1996); Wilbraham (1996); Sehlapelo and Terre Blanche (1996); Terre Blanche (1997); Davies and Terre Blanche, (1997); Payze (1997); Suffla (1997); Levett, et al. (1997); Stevens and Tighe Doerr (1997); Durrheim \& Dixon (1998); Butchart (1998), Minnaar, et al. (1998); Thatcher and Feldman (1998); Esterhuizen (1999) and Macleod (2002).

A closer look at qualitative research locally leads to, among other things, the following observations:

First, while qualitative research has been conducted for at least four decades in South Africa, there has been keen interest among scholars to utilise qualitative methods in local research, particularly starting in the late 1970 s and escalating since the 1990s. It seems fair to state that in terms of Denzin and Lincoln's (2000) developmental stages of qualitative research, many local qualitative studies resemble the modernist paradigm, and there is some interest in the postmodernist phases, most noticeably the blurred genres and crisis of representation paradigms. While it is conceivable that there would be local qualitative research that could be typified as belonging to the so-called fifth moment, it seems from the limited literature performed for this contribution unlikely that much of South African work would reflect the so-called sixth moment or "postexperimental" phase. Similar to the state of qualitative research abroad, but to a lesser degree, "contemporary qualitative research in South Africa is characterised by plurality based on the variety of philosophical, theoretical and methodological approaches utilised in the field" (Mouton \& Muller, 1998: 14). While one might expect that local debate and controversy might increase locally as local qualitative research reached the same level of development as such research abroad, it is interesting to note that there has been, except for a workshop Lipsey presented in Pretoria in 1994 (Louw, 1998), no real recent antagonism between proponents of qualitative and quantitative approaches in South Africa as was evident in many American universities (cf. Mouton, 1983 \& 1985; Schurink \& Schurink, 1988; Mouton \& Muller, 1998).

Second, all the known traditions and types of qualitative research are found in local qualitative studies. South Africans have often used single methods, like unstructured interviews, but more recently, many have started employing multimethods, i.e., in-depth interviews, participant observation and/or documents of life.

Third, not uncommon to what is found in qualitative research abroad, local scholars, started utilising qualitative methods and approaches in evaluation research particularly since the late 1980s. While evaluation research is still very much a fledging discipline in South Africa, it seems that Guba and Lincoln's (1989) qualitative approach to evaluation has been quite popular. While many local scholars in the evaluation field would like researchers in general probably agree to the use of both qualitative and quantitative approaches to research generally, and evaluation particularly, there are indications that local scholars are to an increasing extent employing both qualitative and quantitative methods in research in our part of the world. Examples are the works of Van der Burgh (1984), Schurink and Schurink (1990b), Schurink et al. (1993), Schurink, (1999), and Page, et al. (2001).
Fourth, as far as analytic traditions of qualitative research are concerned, while local scholars have used all the known methods, like analytic induction, (AI) phenomenological analysis, discourse analysis and grounded theory (GT), the latter is particularly popular. Mouton et al. (2001, p. 501) write: "Grounded theory is one of the most commonly used approaches in qualitative research in South Africa, especially in theses and dissertations".

Fifth, a particularly distinct example of local postmodernism is found in a debate surrounding the relevance of "the discursive paradigm". This debate, which is according to Macleod (2002), related to discourse analysis and progressive or critical politics, involved quite a few prominent local scholars including Van Staden (1998), Painter and Theron (2001), Terre Blanche (1998), and Durrheim (2001)

Finally, much of local qualitative data analysis, especially of small qualitative studies involving a few research participants, has been done manually, but there is an increasing interest in employing Computer-Aided Qualitative Data Analysis software, or CAQDAS. Mouton et al. (2001) found that most local usage, training and support currently in South Africa is for winMAX and ATLAS.ti.

Having briefly considered the status of qualitative research both abroad and locally, we now turn to a concise review of qualitative research in the organisational/management field.

\section{QUALITATIVE RESEARCH AND ORGANISATIONAL/ MANAGEMENT STUDIES: BRIEF OBSERVATIONS}

In reviewing the application of qualitative research in the organisational/management field, we first take a look at the international scene, after which we turn to the situation in South Africa.

\section{International qualitative management research}

A few good sources of qualitative organisational/management studies ${ }^{5}$ are currently available that discuss the origin, evolution and current state in the field ${ }^{6}$. From a scan of these works, the following inferences seem to be practically striking:

(i) Origin and development. Qualitative research has been used intermittingly in management and organisational studies since their inception (Locke \& Golden-Biddle, 2002). During the 1950s and 1960s classic studies were undertaken: (a) Dalton's (1959) study into managerial practices in four companies in North America, (b) Sayles's (1964) research into the nature of managerial tasks in a particular division of a large American manufacturing organisation, (c) Gouldner's (1954b) research into aspects of a bureaucracy in a gypsum mine, (d) Sayles's (1958) work on shop-floor matters of industrial work groups, (e) Gouldner's (1954a) wildcat strike research, and (f) Lupton's (1963) study of the work organisation and culture of the shop-floor in two manufacturing plants attempting to explain the occurrence of restriction of output by employees (Gill \& Johnson, 2002). Hatch (1997) points out that as far as the history of qualitative research is concerned, the so-called moments or phases in its development are also found in management studies. It is consequently currently common practice to speak of qualitative research as falling within one of the three paradigms: modern, interpretive and postmodern.

(ii) Modenist qualitative research is inter alia evident in content analysis. Boyatsis (1982), attempting to determine which managerial features were related to effective performance, draws on this and related practices. Locke (2001, p. 8) writes: "In one phase of the study, transcripts were developed from interviews during which respondents were asked to describe incidents of on-the-job effectiveness and

5 "Organisational" and "management" researchers and research will be employed interchangeable here.

6 Arguably the most important of these works are those of: Symbol and Cassel (1998), Lee (1999), Lee, et al. (1999), Gummesson (2000), and Collins and Hussey (2003) 
ineffectiveness. A coding system was developed to analyze these interview-based observations. Previous work provided the basis from which 19 conceptual categories that comprised this study's coding system were developed. The interview transcripts were independently coded by two coders for frequency of occurrence of each of the 19 categories. The frequencies determined for the conceptual categories then formed the basis for making comparisons of managers in high, average, and low performance groupings. The resulting correlations pointed to those characteristics that distinguished high from low performance". From this study, it is clear that modernist qualitative researchers share with their quantitative colleagues an apprehension for the nature of the relationship between their revealed facts and the observable world that these claim to explain.

(iii) Interpretive and related constructivist paradigms. Exponents of this paradigm are interested in understanding the world of lived experience from the point of view of those who live it. They focus on particular situated actors who they see as compromising out of events and phenomena through longlasting processes of interaction that include history, language and action. As a result, social reality is not a given but is built up over time through shared history, experience and communication so that what is taken for "reality" is what is shared and taken for granted as to the way the world is to be perceived and understood. In order to appreciate the lived world of experience, qualitative researchers must engage with and participate in it; they must actively interpret it (Locke, 2001). Examples of qualitative management work include: Weick's (1969) enactment theory, which highlights the active role that organisation members play in creating the very organisations in which they work; Gephart's (1978) study of organisation succession that concentrate on the language and activities through which succession is developed; Isabella's (1990) research of middle managers in a financial service institution, accentuating that changes in managers' understanding and interpretations of organisational events are necessary in order for change process to develop; and Bartunek's (1984) study of a religious order that looks at the relationship between organisation members' interpretive schemes and organisational structure (Locke, 2001).

(iv) The postmodern paradigm. Popularized in the arts, literacy, criticism and philosophy, "postmodern" entails a variety of ideas, among others examining how power relations benefit particular worldviews while silencing others. "Postmodernism suggests that what is taken for 'reality' is constructed by the discursive or language systems put in play by a particular social historical context - what is 'real' then is what is represented as such. And, researchers' own attempts at uncovering 'reality' should also be seen as forms of discourse...Indeed, postmodern theory has as one of its aims the deconstruction of grand narratives of truth and knowledge..." (Locke, 2001, p. 11).

Examples of post-modern work in management studies are, among others: Calas and Smircich's (1990) work that study organisational theoretizing on leadership, drawing on feminist deconstructive schemes to draw attention to the cultural influences and constraints on this 'knowledge'; Martin's (1990) illumination of gender in an organisation's response to the maternity leave of one of its female officials; Boje's (1995) explanation of the numerous and concealed realities that form Disney; and Covaleski et al.'s (1998) use of Foucault's ideas about power and knowledge to describe how mentoring and management by objectives work as techniques of control (Locke, 2001). Finally, a recent thoughtful discussion and evaluation of postmodern theory and research is Hancock and Tyler's (2001) work. (v) Approaches of qualitative research widely used in organisational studies. The preceding paradigms do not account for all the diversity found in present- day qualitative management research. "Besides working from different research paradigms, qualitative investigators also work in various approaches or styles that reflect their orientation to particular communities of research practice. Three such communities that are significantly represented among qualitative researchers are ethnography, action research, and case work" (Locke, 2001).

(vi) The repertory grid technique. This technique used in qualitative organisational research is derived from the personal construct theory (Kelly, 1955). It provides a formal method of quantifying qualitative data. According to Stewart and Stewart (1981, p. 5), it allows the researcher when conducting an interview, to obtain a mental map of how the research participant/interviewee views the world, and to write this map up with the minimum of observer bias.

(vii) Mixing qualitative and quantitative research methods. While limited, there are instances where qualitative organisational researchers supplement their studies with quantitative methods (cf. Barley, 1990, Eisenhardt, 1989).

(viii) Vague information on qualitative data analysis. Management researchers utilising qualitative methods generally provide weak descriptions of how they analysed their data. Nevertheless, the most important analytical methods of qualitative research are utilized. Particularly noticeable is grounded theory $(\mathrm{GT})^{7}$, analytic induction (IA) ${ }^{8}$, content analysis ${ }^{9}$ and phenomenological analysis. While symbolic interactionism underpinning grounded theory (GT) has not surfaced in management and organisational studies, it seems to be appealing to researchers including those trained at the business school, who tend to emphasize a logico-deductive approach. Notwithstanding their interest in GT resources and discussions of the method, it is spread across various social science disciplines making it difficult for organisational and management scholars to track them down, resulting in their selective applying of its logic and practices. This invisibility of GT leads Locke (2001) to restore and reveal more fully the future usage of the grounded approach in organisational and management studies. She attempts to materialize this by (i) detailing the disciplinary school of thought and procedural details of the approach as it has been articulated by its architects, and social scientists since the 1970s, and by (ii) discussing the use of GT in organisational and management studies over the same period.

(xi) Organisational researchers take a relatively narrow view of qualitative research. "Glaser and Strauss's (1967) now classic book on grounded theory was the most common methodological citation. Eisenhardt's (1989) case study research design on the speed in strategic decision making was the reference cited next most often (Larson \& Lowendahl, 1996, suggest that Eisenhardt's study appears to be moving towards the status of a 'classic work'). Finally, Yin's (1984) book on case study research was the methodological reference cited third most often" (Lee, 1999, p. 15).

Before concluding this overview of qualitative organisational research abroad, it is worthwhile to present the views of Crafford, a scholar of the Department of Human Resource Management at the Rand Afrikaans University, on qualitative trends in local organisational studies, as set out in an email to me in 2001:

"I see Human Resource Management drawing from amongst other disciplines, from psychology (particularly industrial psychology) and the management sciences. Traditionally both psychology and management sciences have been placed firmly in an empirical-analytical paradigm and have been fairly positivistic in nature. I think the idea of prediction and

7 Argubly the most prominent qualitive organisational researcher in the grounded theory tradition is Locke (2001).

8 While examples of A1 in management research are hard to find, Lennon and Wollin (2001) represent a recent example. In addition, Johnson (1998) discussess the usage of analytic induction in management research.

9 Content analysis entails a way of systematically translating text to numerical variables for quantitive data analysis. When applied to qualitive data it has a number of advantages. Silverman (1993) provides a qualitive usage of this method. By analysing advertisements for information systems professionals placed in four major newspapers between 1970 and 1990, Todd, McKeen and Gallupe (1995) examined changes represented in the knowledge and skills requirements of information systems positions. 
control appealed in an organisational setting where people needed to be managed towards productivity and effectiveness. The idea of being able to control people in service of profit was a good one. The field was (and I think still is) dominated by quantitative research because numbers give one a sense of exactness, which is appealing. I think over time people have become more aware that exactness is not always possible and there is a lot in organisations that has to do with meaning - something you can't really quantify immediately things like organisational culture, symbols and identity come to mind. One is working with people's perceptions and thus other methods are necessary qualitative methods.

I see three paradigms in research: empirical-analytical, interpretive and the critical (constructionist) paradigm. I believe qualitative and quantitative methods can be used in any of the paradigms although the underlying assumption of the paradigm will determine how the method is used and what the implications are for reliability, objectivity and validity. I also believe that each has its place in organisations and that one should be guided by the research problem as to which paradigm and method will be most appropriate. I do however think that quantitative methods have dominated the scene for too long and to the detriment of the field. I think there is a lot still to be explored in organisations, using qualitative methods particularly from an interpretive perspective. I think the critical paradigm with its focus on change and intervention is also important in organisations - very often this work is done all the time, for example change in management interventions - but is never really viewed as research" (Schurink, 2001).

In the light of the present state of qualitative organisational/ management research abroad, it seems fitting to conclude with the following two recommendations:

- Lee (1999, p. 17): "As such, it may be timely for organisational scientists to take a deeper look at methods and tactics of qualitative research for both generating and testing management theories."

- Locke and Golden-Biddler (2000, p. 115-116): "While the variety (in qualitative research in the study of life at work) opens the doors to studying many different features of life at work, it brings serious challenges to those interested in pursuing and those who have to review qualitative research. Coherence in paradigmatic stance, research operations, and the written research accounts become a central issue. For example, the modernist, interpretive, and postmodernist viewpoints make assumptions about the nature of reality and the nature of the act of research that are incommensurate. To avoid mixing and muddling paradigms and research approaches, researchers need to make explicit choices about their epistemological viewpoints and their research approaches and to execute their research projects accordingly ... And journal editors need to ensure they have the requisite variety in their set of reviewers and to assign manuscripts appropriately. This is critical to ensuring the ongoing development of the practice of qualitative research and its ability to contribute to our understanding of life at work."

\section{Qualitative research in local management/ \\ organisational studies}

From a literature search I conducted, I was unable to find any state of the art literature on organisation science and qualitative research in South Africa, confirming Mouton and Muller's (1998) observation that qualitative studies are difficult to find outside the local disciplines of anthropology and history. Therefore the following conclusions I reached must be regarded as tentative and awaiting systematic scrutiny:

(i) As is the case with qualitative research in South Africa local institutions of higher learning generally do not appear to have a tradition of training in qualitative research methods in their Departments responsible for human resources management and related study areas. This unfortunate state of affairs is due to inter alia the exclusion of research methodology of tertiary institutions in favour of the "need for the operational relevance of knowledge". Schreuder (2001, p. 4) writes: "A subject such as research methodology is increasingly being excluded at undergraduate level. It is probably not regarded as a key subject in human resource management. The development of a scientific approach to problems is hampered by those who plan to make a career in industrial psychology". Except for a few exceptions, most notably the Department of Human Resource Management at the Rand Afrikaans University, it appears that local university departments have neither developed particular curricula for qualitative research in management studies nor industrial psychology, and when they do provide such training, it generally takes place on an ad hoc basis ${ }^{10}$.

(ii) At least two local journals, namely the SA Journal of Industrial Psychology and South African Journal of Psychology, accept articles based on qualitative management research, and have already published quite a few excellent articles. These journals together with the South African Qualitative Methods Conference presented annually provide a platform where interchange of ideas between South Africans undertaking qualitative work in life at work could take place, which might in turn contribute to the development of this field in the country.

(iii) At least some organisational qualitative research in South Africa resembles at least the modernist paradigm (cf. Vosloo \& Barnard, 2002; Vermeulen, 2002; Vermeulen, et al. 2003).

(iv) As is the case with qualitative research in South Africa qualitative organisational research in South Africa generally does not represent only one type or a single tradition; it utilizes different methods and traditions. Some recent examples are: focus groups (De Beer \& Barnes, 2003; Vosloo $\&$ Barnard, 2002), repertory grid technique (Vermeulen, 2002; Vermeulen, et al. 2003), interviews (Linde, Rothmann \& Sieberhagen, 1999) and documentary sources (Tlou \& Schurink, this volume).

(v) As far as data analysis methods are concerned, South Africans have used different methods: general informal methods (Vosloo \& Barnard, 2002), grounded theory: Du Toit, 2002; Groenewald, Strümpfer \& Lessing, 2001; Williams, Crafford \& Fourie, 2003; phenomenological analysis (Linde, Rothmann \& Sieberhagen, 1999), and analytic induction (Tlou \& Schurink, this volume).

(vi) There are indications that local scholars are to an increasing extent employing both qualitative and quantitative methods in research in our part of the world. Two recent examples are found in the work of Vermeulen (2002), Vermeulen, et al. (2003) and Cilliers (2002).

Having reviewed the variety of theoretical perspectives informing qualitative research, we now leave the world of theory and enter the world of practice and pragmatism. Differently stated, we present nine qualitative studies that have recently been undertaken in the local study of life at work.

\section{INTRODUCING THE ARTICLES}

Apart from not having been published before and apart from their quality, the articles that are presented in this volume have been selected on their illustration of a particular variety of qualitative research in management studies, for example, the data collection and inferential methods used and/or tradition or paradigm represented.

Article one written by De Villiers and Kotze entitled: Work-life balance: A study in the Petroleum Industry, represents an example of a case study as well as how interviews could be used in qualitative research. 
Articles two and three, both by Tlou and Schurink and dealing respectively with a gay woman's experiences during her career in the Department of Defence and relating relevant social science constructs to her views, in addition to illustrating a particular type of case study, reflect the usage of a solicited human/personal document and a particular formal technique of qualitative data analysis, known as analytic induction.

Article four by Hodgson and Zaaiman (Facilitative Project Management: A model for Integrated Change Implementation) presents an interesting illustration of how they went about in analysing a number of case studies.

Article five "From the worst to the best": an exploratory qualitative study of the process of social change at a South African secondary school created by Van Aswegen and Schurink, illustrates how the methodology they used and the analytic process utilized during the study were guided by certain assumptions of phenomenology, symbolic interactionism and grounded theory. Second, it provides an example of the utilization of multi-methods, e.g. solicited essays and focus groups. Finally, it indicates an inductive form of analysis, called grounded theory.

Article six by Chawane, Van Vuuren and Roodt, entitled Personal change as a key determinant of the outcomes of organisational transformation interventions, demonstrates how content analysis could be performed, and how electronic mail could be employed to contact research participants and distribute research questions to them.

Article seven, by Whitehead and Kotze, which reports on a study of the career and life balance of local professional women, provides another example of the utilization of multiple qualitative data collection techniques, in-depth interviews and a focus group session, as well as the analytic technique of grounded theory.

De Jager, Cilliers and Veldsman in their Leadership development from a systems psychodynamic consultancy stance (article eight) furnish another illustration of focus groups as a data collection method, and grounded theory as an inferential method.

The final contribution (article nine) by Groenewald and Schurink, entitled The contribution of co-operative education in the growing of talent in South Africa, offers an example of the usage of phenomenology in a qualitative exploration.

\section{CONCLUSION}

From the preceding discussion and borne out by the nine qualitative contributions in this volume of the Journal, it is clear that qualitative research is "alive" in organisational/ management and related areas and disciplines in South Africa, but as to its being "well", hard work seems to be required not only to sustain it in our part of the world, but also to expand it by taking advantage of developments and trends abroad.

I firmly believe that anyone who is truly committed to create an optimally managed and profitable industry in the "Rainbow Nation" and believes that the social sciences generally and qualitative research particularly are necessary for such a course will recognise the tremendous responsibility resting on the shoulders of the younger generation of qualitative researchers in the organisational and other fields of study to undertake quality research that can inform local management policy. From my own experience of lecturing local students on qualitative research methods, I am convinced that only experienced researchers who are ready to lend committed youngsters who display particular personal qualities a hand can fulfil this task. More particularly, we need to develop and employ experimental pedagogies that are in line with the characteristics of our students and facilitate joint ventures with them in order for the young Turks to develop into dedicated and creative researchers who are well-equipped to explore, describe and explain the many ways people in post-Apartheid South Africa creates their work - and assigns meaning to other areas of their lives.

I have been very privileged over the last two and a half decades to have been intermittently part of various local training courses and schools on qualitative research methods and I thought it might be appropriate and hopefully of some value to share, in conclusion, some experiences and thoughts on the training of local qualitative researchers in the field of industrial psychology and organisational research.

From my recollection of some training courses, lectures and workshops, it was apparent that being taught qualitative research is often quite a threatening experience for students and attendants. This has been borne out by a scan of the limited literature available on qualitative research training courses. Such anxiety appears to be caused mainly when students' taken-for-granted assumptions about various philosophical and theoretical assumptions are infiltrated and confronted. From my own experience, I have found that some course attendants, particularly colleagues from research institutions and universities, attended my lectures out of sheer curiosity and/or because their superiors or colleagues expected them to attend any course presented in order to bring back new ideas to their institutions. In my view, very few, if any, of these attendants have ever seriously considered conducting qualitative research themselves or guiding students who wanted to undertake such research. From discussions with them, it became clear that many of these young colleagues hold positivistic-oriented scientific beliefs that prevent them from participating fully in qualitative training courses, let alone undertaking qualitative research.

The fact that a great variety of traditions are nested under the qualitative umbrella today as well as the very nature of qualitative research contribute to the complexity of training students.

It appears that field-based qualitative training courses, where students are taken through key aspects, if not the entire qualitative study, and are given guided experience doing field-based research, have proven to be particularly successful since the students experience how methods take shape as they become immersed in actual social life. However, there are obstacles inherent in the typical university course, specifically temporal constraints, e.g. the inclusion of qualitative research methods alongside quantitative methods and theory.

My own local qualitative research courses where I have been presenting formal lectures on the nature of qualitative research, its underpinning philosophies and theories, its various data collection and analysis methods, involving the course attendants in role-plays in class, and enrolling them in a few hour visits to natural semi-public settings or small-scale worlds, like pubs, restaurants, emergency hospital wards, and streets where prostitutes solicit passers-by, have proved to be remarkably successful. Feedback received from the course attendants, including lecturers, postgraduate students, police officials, employees and researchers working in provincial legislative offices, have thus far been very positive without exception. These attendants' evaluation accounts which vary from the course having provided handson experience of qualitative methods, having being active and exciting instead of passive often boring learning experience, have introduced innovative and creative ways of unpacking peoples' experiences and feelings, and have provided insight into everyday life activities of communities in which the attendants themselves live. Excluding attendants 
who because of their particular scientific views are opposed to qualitative research, the negative assessments received were typically that the course was too short and that more time should have been provided - especially for the study of local natural settings.

\section{REFERENCES}

Ashley, M., Padayachee, M., \& Holderness, W.L. 1996. The implementation of the Thousand Schools Project during 1955: an evaluation. Cape Town: Independent Development Trust.

Babbie, E. \& Mouton, J, (with contributions by: Payze, C., Vorster, J., Boshoff, N., \& Prozesky, H.) 2001. The practice of social research. South African edition. Cape Town: Oxford University Press Southern Africa.

Ball, M.S. \& Smith, G.W.H. 1992. Analyzing visual data. Newbury Park, CA: Sage.

Ballen, L., Koloane, D., Potter, C.S., Ramogase, A., \& Siwani, J. 1991. An evaluation of the Khula Udweba Project: 1989-1990. Centre for Continuing Education, Report and Reprint Series No 104. Johannesburg: University of the Witwatersrand.

Barley, S.R. 1990. The alignment of technology and structure through roles and networks. Administrative Science Quarterly, 35, 61-103.

Bartunek, J. 1984. Changing interpretive schemes and organisational restructuring: the example of a religious order. Administrative Science Quarterly, 29, 355-372.

Becker, H.S. 1995. Visual sociology, documentary photography, and photo-journalism: It's (almost) all a matter of context. Visual Sociology, 10 (1-2): 5-14.

Berger, S. 1990. An 'inside story' - the illness experiences of women with breast cancer. Unpublished Masters dissertation. Cape Town: University of Cape Town.

Bogdan, R. \& Biklen, S.K. 1998. Qualitative research for education. An introduction to theory and methods. Boston: Allyn \& Bacon.

Boyatsis, R.E. 1982. The competent manager: a model for effective performance. New York: Wiley.

Boje, D. 1995. Stories of the storytelling organisation: a postmodern anmalysis of Disney as "Tamara-Land". Academy of Management Journal, 38, 997-1035.

Bozzoli, B. 1990. Intellectuals, audiences and history: South African experiences 1987/1988. Radical Historical Review, 46 (7): 237-263.

Brown, L. 1997. A discursive analysis of the role of tertiary educational institutions in reproducing racism. Unpublished Masters Dissertation. Pietermaritzburg: University of Natal.

Bryman, A. 1984. The debate about quantitative and qualitative research: A question of method or epistemology? The British Journal of Sociology, 35 (1): 75-92.

Bulbring, R. 1998. The near-death experience and it's bearing on the survival problem: a multiple case study. Unpublished Phil D. thesis. Grahamstown: Rhodes University.

Burgess, R.G. 1984. In the field: An introduction to field research. London: Allen \& Unwin.

Butchart, A., Lerer, L.B.,\& terri Blanche, M.J. 1994. Imaginary constructions and forensic reconstructions of fatal violence against women: implications for community violence prevention. Forensic Science International, 64, 21-34.

Calas, M.B. \& Smircich, L . 1990. Voicing seduction to silence leadership. Organisational Studies, 12, 567-602.

Cleaver, G. 1988. A phenomenological analysis of victimization. The experience of having one's house attacted and dam,aged. South African Journal of Psychology, 18, 76-83.

Cleaver, G. \& Pallourios, H. 1994. Diabetes mellitus: experiencing a chronic illness. South African Journal of Psychology, 24, 175-183.

Covaleski, M.A., Dirsmith, M.A., Heian, J.B. \& Samuel, S. 1998. The calculated and the avowed: techniques of discipline and struggles over identity in big six public accounting firms. Administrative Science Journal, 43, 293-327.
Davidoff, S., \& Van den Berg, O. 1990. Changing your teaching: the challenge of the classroom. Pietermaritzburg: Centaur.

Davies, S. \& Terre Blanche, M. 1997. Training to care: an evaluation of a bereavement counselling course. Journal of Educational Evaluation, 5, 49-55.

Dawson, J., \& Scott, J. 1996. Elevator etiquette. Paper presented at the $2^{\text {nd }}$ annual South African Qualitative Methods Conference, (3-4 September) Johannesburg.

Delius, P. 1996. A lion amongst the cattle: reconstruction and resistance in the Northern Transvaal. Johannesburg: Raven.

Dixon, J.A., Foster, D.H., Durrheim, K., \& Wilbraham, L. 1994. Discourse and the politics of space in South Africa: the 'squatter crisis'. Discourse \& Society, 5, 277-296.

Chaplin, E. 1994. Sociology and visual representation. New York: Routledge.

Cilliers, F. 2002. Salutogenic coping with burnout among nurses. A qualitative study. South African Journal of Labour Relations, 26 (4): 61-85.

Creswell, J.W. 1998. Qualitative enquiry and research design. Choosing among Five traditions. Thousand Oaks, Ca: Sage.

Crafford, A. 2001. Qualitative research. E-mail correspondence, 23 April.

Crotty, M. 1998. The foundations of social research: meaning and perspective in the research process. London: Sage.

Coffey, A. \& Atkinson, P. 1996. Making sense of qualitative data: Contemporary research strategies. Thousand Oaks, CA: Sage.

Collis, J. \& Hussey, R. 2003. Business research. A practical guide for undergraduate and postgraduate students. New York: Palgrave Macmillan.

Crause, H.L. \& Botha, P.M.C. 1977. Prostitution: an analysis of the social system centred in the harbour area of Port Elizabeth by night. Port Elizabeth: University of Port Elizabeth (Youth research project: Publication Number 3).

Dalton, M. 1959. Men who manage. New York: Wiley.

De Beer, M. \& Barnes, N. 2003. The assessment of intellectual capital (IC) in the South African context - a qualitative approach. SA Journal of Human Resource Management, 2003 1 (1), 17-24.

Denzin, N.K. 1989. Interpretative biography. Newbury Park, CA: Sage.

Denzin, N.K. \& Lincoln, Y.S. (Eds). 1994. Handbook of qualitative research. Thousand Oaks, CA: Sage.

Denzin, N.K. \& Lincoln, Y.S. 2000. (Eds.). Handbook of qualitative research $2^{\text {nd }}$ ed. Thousand Oaks, CA: Sage.

Denzin, N.K \& Lincoln, Y.S. 2000. Introduction: the discipline and practice of qualitative research. In N.K. Denzin, \& Y.S. Lincoln, Y.S. (Eds.). Handbook of qualitative research $2^{\text {nd }}$ ed. Thousand Oaks, CA: Sage, Pp. 1-28.

Durrheim, K. 2001. A defence of an 'immanentist ' account of social form and experience. South African Journal of Psychology, 31, 9-11.

Du Toit, S.W. 2002. Virtual employees: A grounded theory of the impact on HRM. Dissertation. Johannesburg, Rand Afrikaans University. Eckert, P. 1989. Jocks \& burnouts: social categories and identity in the high school. New York: Teachers College Press.

Eisenhardt, K.M. 1989. Making fast decisions in high-velocity environments, Academy of Management Journal, 32, 543-576.

Engelbrecht, E. 1991. Slagoffers van bomaanvalle in Johannesburg: 'n Kriminologiese ondersoek. Unpublished Doctor Litterarum Et Philosophiae. Pretoria: Universiteit van Suid -Afrika.

Esterhuizen, L.P. 1999. On method and madness: ambivalence and contingency in social research. M. Phil. (Social Science Methods) stellenbosch: University of Stellenbosch.

Esterhuysen, R, Jordaan, R., Schurink, E., Schurink, W.J., Smit, J., Snyman, P.H.R. \& Steyn, M. 1994. Prison health care services: legislation, perceptions and statistics. (Report to the Department of National Health and Population Development). Pretoria: HSRC.

Euvrard, G.E. 1996. An exploration of the factors which mediate the experience of parenting in an open adoptive parenting system. Unpublished Honours research project. Grahamstown: Rhodes University. 
Evans, S. 1998. Contextual interpretations of sexual fantasy. Unpublished Masters Dissertation. Johannesburg: University of the Witwatersrand.

Ferreira, M. 1988. A sociological analysis of medical encounters of aged persons at an outpatient centre: a qualitative approach. In M. Ferreira, J. Mouton, G. Puth., E. Schurink, W. Schurink, (Eds.). Introduction to qualitative research. Pretoria: Human Sciences Research Council.

Ferreria, S. 'n Kwalitatiewe ondersoek na die emosionele belewenis van Suid-Afrikaanse blanke geskeide mans. Ongepubliseerde Magister in Maatskaplike werk. Pretoria: Universiteit van Pretoria.

Gephart, P. 1978. Status degradation and organisational succession: an ethnomethodological approach, Administrative Science Quarterly, 23, 553-581.

Germond, S., Schomer, H., Meyers, O., \& weight, L. 1993. Pain management in rheumatoid arthritis. South African Journal of Psychology, 23, 1-9.

Gill, J. \& Johnson, 2002. Research methods for managers. $3^{\text {rd }}$ ed. Thousand Oaks, CA: Sage.

Giorgi, A. 1997. The theory, practice, and evaluation of the phenomenological research procedure. Journal of Phenomenological Psychology, 28 (2): 235-260. (Phenomenological analysis.)

Gouldner, A.W. 1954a. Wildcat strike. New York: Harper \& Row.

Gouldner, A.W. 1954b. Patterns of industrial bureaucracy. Glencoe, NY, Free Press.

Graham, P.M. \& Zungu, V.E. 1987. Edendale lay ecumenical centre evaluation report. Pietermaritzburg: University of Natal Centre for Adult Education.

Glaser, B. \& Strauss. 1967. The discovery of grounded theory: strategies for qualitative research. New York: Aldine De Gruyter.

Graser, R.R. 1992a. A study of selected cases of family murder in South Africa. Pretoria: HSRC.

Graser, G.G. 1992b. Victimization and victim precipitation in family murders. In W.J Schurink, I. Snyman \& W.F. Krugel (assisted by L. Slabbert) (Eds.). Victimization: nature and trends. Pretoria: Human Sciences Research Council. Pp. 357-385.

Groenewald, J., Strümpfer, D. \& Lessing, B. 2001. Acceptance of co-operative education practice by the academic staff at Technikon Southern Africa, Journal of Industrail Psychology, 27 (3), 1-6.

Guba, E.G. \& Lincoln, Y.S. 1994. Competing paradigms in qualitative research. In: N.K. Denzin, \& Y.S. Lincoln, (Eds.). Handbook of qualitative research. Thousand Oaks: Sage.

Gummesson, E.2000. Qualitative methods in management research. $2^{\text {nd }}$ ed. Housand Oaks, CA: Sage.

Hancock, P. \& Tyler, M. 2001. Work, postmodernism and organisation: a critical introduction. London: Sage.

Hatch, M. 1997. Organisational. Modern symbolic, and postmodern perspectives. Oxford: Oxford University Press.

Hay, W. 1998. Discourse as power relations: concepts of self within situations of abuse of women in the traditional Roman Catholic marriage. Unpublished Master Dissertation. Johannesburg: University of the Witwatersrand.

Isabella, L.A. 1990. Evolving interpretations as a change unfolds: how managers construe key organisational events. Academy of Management Journal, 33, 7-41.

Ivey, G., \& Simpson, P. 1998. The psychological life of paedophiles: a phenomenological study. South African Journal of Psychology, 28 (i), 15-20.

Kaminer, D., Dixon, J. 1995. The reproduction of masculinity: a discourse analysis of men's drinking talk. South African Journal of Psychology, 25, 168-174.

Kelly, 1955. The psychology of personal constructs: a theory of personality. New York: Norton.

Jacob, E. 1987. Qualitative research traditions: a review. Review of Educational Research, 57 (1): 1-50.

Johnson, P. 1998. Analytical induction. In C. Cassell \& G. Symon (Eds.). Qualitative methods and analysis in organisational Research. London Sage.
Johnson, P. \& Duberley, J. 2000. Understanding management research. Thousand Oaks, CA: Sage.

Kruger, 1988. The problem of interpretation in psychotherapy. Pretoria: HSRC.

Kvale, S. 1996. Interviews: An introduction to qualitative research interviewing. Thousand Oaks, CA: Sage.

Larsson, R. \& Lowendahl, B. 1996. The qualitative side of management research. Paper presented at the annual meeting of the Academy of Management, Cincinnati, OH. (April). Quoted in Lee, T.W. 1999. Using qualitative methods in organisational research. Thousand Oaks, CA: Sage.

Lee, T.W. 1999. Using qualitative methods in organisational research. Thousand Oaks, CA: Sage.

Lee, T.W., Mitchell, T.R., \& Sablynski, C.J. 1999. Qualitative research in organisational and vocational psychology, 19791999. Journal of Vocational Behavior, 55, 161-187.

Lennon, A. \& Wollin, A. 2001. Learning organisations: empirically investigating methaphors. Journal of Intelectual Capital, 2 (4), 410-422.

Levett, A. 1989. Psychological trauma: discourses of childhood sexual abuse. Unpublished Doctoral thesis. Cape Town: University of Cape Town.

Levett, A. 1990. Discourses on childhood sexual abuse. In J. Mouton \& D. Joubert, (Eds.). Knowledge and method in the human sciences. Pretoria: Human Sciences Research Council. Pp. 343-355.

Levett, A., Kottler, A., Burman, E., \& Parker, I. (Eds.). 1997. Culture, power and difference: discourse analysis in South Africa. London: Zed Books.

Linde, L.H., Rothmann, S. \& Sieberhagen, G.V.D.M. 1999.Senior besdtuurders in 'n openbare maatskappy se belewing van loopbaanontwikkeling. Journal of Industrial Psychology, 25 (2), 13-20.

Lindegger, G., \& Bosman, P. 1990 A systems view of chronic illness and its management African Journal of Psychology, 20, $32-41$.

Locke, K. 2001. Grounded theory in management research. Thousand Oaks< CA: Sage.

Locke, K. \& Golden_Biddle, K. 2002. An introduction to qualitative research: It's potential for Industrial and Organisational Psychology. In: S.G. Rogelberg (Ed.). Handbook of Research Methods in Industrial and Organisational Psychology. Oxford: Blackwell Publishers. Pp. 99-118.

Lofland, J. \& Lofland, L.H. 1984. Analyzing social settings: A guide to qualitative observations and analysis. $2^{\text {nd }}$ ed. Belmont: Wadsworth.

Lotter, H.P.P. 1995. Kwantitatiewe of kwalitatiewe navorsing? 'n Wetenskapfilosofiese perspektief. [Quantitative or qualitative research? A scientific-philosophical perspective.] Acta Academica, 27 (3).

Lötter, J.M. \& Schurink, W.J. 1984. Gevangenisbendes: 'n Ondersoek met spesiale verwysing na nommerbendes onder Kleuringgevangenes. Pretoria: RGN.

Louw, J. 1998. Programme evaluation: A structured assessment. In J. Mouton, Muller, P., Franks, \& T. Sono (Eds.), Theory and method in South African human sciences research: Advances and innovations. Pretoria: HSRC, pp. 255-268.

Lupton, T. 1963. On the shop floor. Oxford: Pergamon.

MacDonald, A. 1993. Commitments and constraints: evaluating the Science Education Project in South Africa. Cape Town: Oxford University Press.

Macleod, C. 2002. Deconstructive discourse analysis: extending the methodological conversation. South African Journal of Psychology, 32 (1), 17-25.

Maconachie, M., Angless, T. \& Van Zyl, M. 1993. Promoting personal safety for women. Women set an agenda for policy formation. Pretoria: Human Sciences esearch Council.

Maree, A. 1995. Die modus operandi van die bankrower: 'n Kriminologiese introspeksie. (Ongepubliseerde Doctor Litterarum Et Philosophiae), Pretoria: Universiteit van SuidAfrika. 
Maree, A., Joubert, S.J. \& Prinsloo, J.H. 1996. Die begrondingsteorie as navorsingsmetode. Acta Criminologica, 9 (2): 47-54.

Martin, J. 1990. Deconstructing organisational taboos: the suppression of gender conflict in organisations. Organisation Science, 1, 339-359.

Mason, J. 1996. Qualitative researching. Thousand Oaks, CA: Sage.

Mayekiso, T.V., \& Bhana, K. Sexual harassment: perceptions and experiences of students at the University of Transkei. South African Journal of Psychology, 24, 230-243.

Mazibuko, K. 1990. Final evaluation report on the Youth Leader Development programme. Centre for Continuing Education, Report and Reprint Series No 97. Johannesburg: University of the Witwatersrand.

Mclaren, P. 1994. Life in schools. $2^{\text {nd }}$ ed. NEW York: Longman.

Merriam, S.B. and associates. 2002. Qualitative research in practice. Examples for discussion and analysis. San Francisco, CA: Jossey-Bass.

McNaught, C., \& Raubenheimer, D. (Eds.). 1991. Critical reflections on teachers in action: an evaluation report of the Natal Primary Science project. Durban: The Urban Foundation.

Meyer, M.I., \& Pinto, D. 1982. Perspectives on an intervention programme for pre-university commerce students. Centre for Continuing Education, Report and Reprint Series No. 2. Johannesburg: University of the Witwatersrand.

Mina, L. 1986. The ideology of rape in Newlands East: a feminist perspective. Unpublished Masters dissertation. Durban: University of Natal.

Minnaar, A., Wentzel, M. \& Payze, C.1998. Witch killing with special reference to the Northern Province of South Africa. In E. Borman, R. Van Eeden, \& M.E. Wentzel, (Eds). Violence in South Africa: A variety of perspectives. Pretoria: HSRC Printers. Pp. 175-199.

Minnaar, G.G., Venter, M.K. \& Schurink, W.J. 1980. 'n Psigodinamiese verkenningstudie van 'n aantal blanke prostitute in Johannesburg. (A psychodynamic exploratory study of some white prostitutes in Johannesburg.) Pretoria: RGN (Navorsingsbevinding SN 194).

Morgan, D.L. 1997. Focus groups as qualitative research. Thousand Oaks, CA: Sage.

Mouton, J. 1983. Kwalitatiewe en kwantitatiewe metodologieë in die sosiale wetenskappe. [Qualitative and quantitative methodologies in the social sciences.] South African Journal of Sociology, 14 (4): 124-131.

Mouton, J. 1985. Contemporary philosophies of science and the qualitative paradigm in the social sciences. South African Journal of Sociology, 16 (3): 81-89.

Mouton, J. 1986. The philosophy of qualitative research. In: M. Ferreria, et al. (Eds.). Module 3: Introduction to qualitative research methods. Pretoria: Human Sciences Research Council. Proceedings of the First HSRC Winter School in Research Methodology, 30 June to 10 July.

Mouton, J. \& Marais, H.C. 1990. Basic concepts in the methodology of the social sciences. Pretoria: HSRC.

Mouton, J. \& Muller, J. 1998. Tracking trends in theory and method: Past and future. Programme evaluation: A structured assessment. In J. Mouton, J. Muller, P., Franks, T. \& Sono (Eds.). Theory and method in South African human sciences research: Advances and innovations. Pretoria: HSRC, pp. 255-268.

Neuman, W.L. 1994. Social research methods: Qualitative and quantitative approaches. Boston: Allyn \& Bacon.

Moeketsi, A. 1998. Psycho-cultural factors mediating the acquisition and use of condoms amongst Black male university students. Unpublished Honours project. Grahamstown: Rhodes University.

Modungwa, N.M. 1995. The experience of mothers caring for their teenage daughters' young children. M. Cur. (Psychiatric Nursing) mini-thesis. Johannesburg: Rand Afrikaans University.

Nembahe, M. 1998. An investigation of mourning amongst urban Zulus in relation to Worden's model of mourning. Unpublished Masters dissertation. Johannesburg: University of the Witwatersrand.
Nomoyi, N.C. \& Schurink, W.J. 1998. Ukunxityiswa Kwempimpi Itayari Njengotshaba Lomzabalazo: An exploratory study of insider accounts of necklacing in three Port Elizabeth townships. In E. Borman, R. Van Eeden, \& M.E. Wentzel, (Eds). Violence in South Africa: A variety of perspectives. Pretoria: HSRC Printers. Pp. 147-173.

Oberholzer, A.E. 1992. Die belewenis van 'n kind in ' $n$ intensiewesorgeenheid. M.Curr. (Intensive General Nursing Science) Unpublished dissertation. Johannesburg: Rand Afrikaans University.

Oliphant, E.M. 1993. Die gesinssisteem waarin dwelmmisbruik voorkom en die maatskaplike werker - 'n sistemiese perspektief. Unpublished D.Litt. et Phil. Thesis. Johannesburg: Rand Afrikaans University.

Page, O., Moeketsi, P., Schurink, W.J., Molefe, L. \& Bruce, D. 2001. Crime and crime prevention on public transport. Pretoria: University of South Africa.

Painter, D. \& Theron, W.H. 2001. Heading south! Importing discourse analysis. South African Journal of Psychology, 31, 1-8.

Palmary, I., Barnes, B. 1998. Bad boys and cool dudes: a study of school bullying. Paper presented at the $4^{\text {th }}$ annual Qualitative Methods Conference (3-4 September) Johannesburg: University of the Witwatersrand.

Patton, M.C. 1997. Utilization-focused evaluation. The new century text. $3^{\text {rd }}$ ed. Thousand Oaks, CA: Sage.

Patton, M.C. 2002. Qualitative research \& evaluation methods. $3^{\text {rd }}$ ed. Thousand Oaks, CA: Sage Publications.

Payze, C. 1997. An overview of computer aided qualitative data analysis techniques. In M.J. Terre Blanche (Ed.). The body politic. Conference proceedings of the $2^{\text {nd }}$ Annual South African Qualitative Methods Conference. Johannesburg: University of South Africa

Potter, C.S. \& Moodie, P. 1992. Charting progress in large scale innovation: two studies - Part two: a formative evaluation of curriculum development in a primary science project. Journal of Educational Evaluation, 1, 50-70.

Pretorius, R. 1984. Die vrou as slagoffer van geweld binne huweliksverband: 'n viktimologiese ondersoek. (Ongepubliseerde D.Phil-proefskrif) Pretoria: Universiteit van Pretoria.

Radway, J. 1984. Reading the romance. Chapel Hill, NC: university of North Carolina Press.

Ramphele, M. 1993. A bed called home: life in the migrant labour hostels of Cape Town. Cape Town: David Phillip.

Rudenberg, S.L., Jansen, P., \& Fridjohn, P. 1998. The effect of exposure during an ongoing climate of violence on children's self-perceptions, as reflected in drawings. South African Journal of Psychology, 28, 107-115.

Roman, L. \& Apple, M. 1990. Is naturalism a move away from positivism? Materialist and feminist approaches to subjectivity in ethnographic research. In E. Eisner, \& A. Peshkin (Eds.). Qualitative enquiry in education: The continuining debate. New York: Teachers College Press. Pp. 38-73.

Roos, L., Bergh, A., Kruger C., Pickworth, G., Schurink, W. \& Van Staden, W. 2002. Final year medical students' social construction/ experiences of 'soft skills' in the 'old' MBChB curriculum of the University of Pretoria (First preliminary draft report) Faculty of Health Science, University of Pretoria, Pretoria, April.

Sayles, 1958. The behaviour of industrial work groups. New York: Wiley.

Sayles, L. 1964. Managerial behaviour: administration in complex organisations. New York: McGraw-Hill.

Shantall, H.M. 1995. A Phenomenological study of the meaning of suffering. Unpublished D.Phil. dissertation. Pretoria: University of South Africa.

Schreuder, D.M.G. 2001. The development of industrial psychology at South African universities: a historical overview and future perspective. Journal of Industrial Psychology, 27 (4), 1-7.

Schurink, W.J. 1979. Seksuele misdaad. In J.M. Lötter, H.G. Strijdom \& W.J. Schurink 1979. (Eds.). Eersterust: 'n Sosiologiese studie van 'n kleurling-gemeenskap. (Sexual crime in Eersterust, a coloured community). Pretoria: RGN, pp. 3 22 tot 32291 (Verslag S 63). 
Schurink, W.J. 1981. Gay vroue: 'n sosiologiese verkenning van die leefwyse van 'n aantal lesbiërs aan die hand van outobiografiese sketse. (Gay women: a sociological exploration of the lifestyle of some lesbians, based on autobiographic sketches.) Pretoria: RGN (Verslag S 74).

Schurink, W.J. 1985. 'n Verkennende studie van prostitusie in Eersterust. In J. Mouton \& H.C. Marais (Reds.). Metodologie van die geesteswetenskappe: Basiese begrippe. (An exploratory study of prostitution in Eersterust.) Pretoria: RGN (RGN studies in Navorsingsmetodologie: 1).

Schurink, W.J. 1989. Die realiteit van homoseksualisme: 'n sosiologies kwalitatiewe ontleding. (The reality of homosexualism: a sociological-qualitative analysis.) Potchefstroom: Potchefstroomse Universiteit vir Christelike Hoër Onderwys. (Unpublished doctoral thesis.)

Schurink, W.J. 1994. The 1994 election and prison violence. Prison managers' views. (Final report to the Department of Correctional Services.) Pretoria: HSRC.

Schurink, W.J. 1999. Programme evaluation: Views and practices from the field and general guidelines for the crime prevention iniatives at the Wynberg, Berea and Marabastad/Belle ombre modal interchanges. (Draft discussion document for the project entitled: Crime Prevention on public transport). Pretoria: HSRC.

Schurink, W.J. 2001. Models of qualitative research. Parts One \& Two. Doctoral Programme: Leadership in Performance and Change. Department of Human Resource Management RAU, Johannesburg. 7-9 May 2001.

Schurink, W.J., De Jongh Van Arkel, J.T. \& Roos, J.L. 1992. Methodological account of the execution of qualitative methods in the family murder study. Geneeskunde, 34 (8): 13-24.

Schurink, W.J. \& Levinthal, T. 1983. Business women exchanging sex for money: a descriptive study. South African Journal of Sociology, 14 (4): 154163.

Schurink, W.J., Liebenberg, I. \& Schurink, E.M. 1993. Commercial sex work. Pretoria: HSRC (Memorandum to Department of National Health and Population Development).

Schurink, W.J., Maphatane, M., Rip, S., Schurink, E.M., Smit, L. \& Tiba, M. 1993. Street children. An investigation into the causes and incidence of the problem of street children in the RSA with the aid to develop a model for treatment, rehabilitation and prevention programmes. Pretoria: Human Sciences Research Council.

Schurink, W.J., Molope, C. \& Tshabalala, S. 1997. Exploring some dimensions of child labour in South Africa. Working document. Pretoria: The Centre for Human Rights, University of Pretoria.

Schurink, W.J. \& Ndabandaba, L.B.G. 1990. Prostitution. In J.M. Lötter, L.B.G. Ndabandaba, \& R. Esterhuysen, R. (Eds.). Crime and its impact: a study in a black metropolitan area research papers. Pretoria: HSRC (Report ASS/BBS 14 RP).

Schurink, W.J \& Schurink, E. M, 1988. Developing practice wisdom into theory: the use of qualitative methodology. The Social Work Practitioner-Researcher, 1 (2): 27-37.

Schurink, W.J \& Schurink, E. M. 1990a. BMs in the Mykonos: Participant observation in a South African gay club. In P. HUGO (Ed.). Truth be in the field: Social science research in Southern Africa. Pretoria: University of South Africa.

Schurink, W.J \& Schurink, E. M. 1990b. AIDS: Lay perceptions of a group of gay men. Pretoria: HSRC (Report S 187).

Schurink, W.J. \& Winterbach, D.J. 1979. "Seks te koop in diensorganisasies" 'n Sosiologiese verkenning van prostitusie in masseersalonne en eskortagentskappe. (Sex-for-sale in service organisations - a sociological exploration of prostitution in massage parlours and escort agencies.) Pretoria: RGN (Navorsingbevinding SN 174).

Sliep, Y. 1994. A CARE - counselling model for AIDS patients in rural Malawi. D.Cur. Unpublished (Psychiatric Nursing) thesis. Johannesburg: Rand Afrikaans University.

Siwani, J. 1986. An evaluation of a pilot programme for training community leaders. Centre for Continuing Education, Report and Reprint Series No. 36. Johannesburg: University of the Witwatersrand
Siwani, J., Dzebu, M., \& Gentin, J.C. 1990. A review of the Youth Leadership Development programme. Centre for Continuing Education, Report and Reprint Series No. 101. Johannesburg: University of the Witwatersrand.

Sodi, T. 1996. Phenomenology as a viable methodological approach to the study of indigenous healing. Paper presented at the $2^{\text {nd }}$ annual South African Qualitative Methods Conference, (3-4 September) Johannesburg.

Steenkamp, A. 1991. Opleiding van sewmbadbestuurders by plaaslike owerhede: 'n Situasie-analise. Ongepubliseerde Magister Artium Verhandeling. Pretoria: Universiteit van Pretoria.

Stevens, P.E. \& Tighe Doerr, B. 1997. Trauma of discovery: women's narratives of being informed that they are HIVinfected. AIDS Care, 9, 523-538.

Steyn, H.C. 1992. Worldviews in transition: a study of the New Age Movement in South Africa. Unpublished Doctor of Literature and Philosophy. Pretoria: University of South Africa.

Stewart, V. \& Stewart, A. 1981. Business applications of repertory grid. Maidenhead: McGraw-Hill.

Strauss, A.L. \& Corbin, J. 1990. Basics of qualitative research: Grounded theory procedures and techniques. Newbury Park: Sage.

Stones, C.R. 1988. Research: toward a phenomenological praxis (pp. 141-156). In D. Kruger. An introduction to phenomenological psychology. $2^{\text {nd }}$ revised edition. Cape Town: Juta.

Suffla, S. 1997. Experiences of induced abortion among a group of South African women. South African Journal of Psychology, 27, 214-222.

Symbol, G. \& Cassell, C. 1998. Qualitative methods and analysis in organisational research: a practical guide, London: Sage.

Swartz, S. 1996. Shrinking: a postmodern perspective on psychiatric case histories. South African Journal of Psychology, 26, 150-161.

Taylor, S.J. \& Bogdan, R. 1984. Introduction to qualitative research methods: The search for meanings. $2^{\text {nd }}$ ed. New York: Wiley.

Terri Blanche, M.J. 1997. 'The knowledge that one seeks to disinter' psychiatry and the discourse of discourse analysis. In A. Levitt, A. Kottler, E. Burman \& I. Parker (Eds.). Culture, power and difference: discourse analysis in South Africa. London: Zed Books.

Terre Blanche, M. \& Durrheim, K. (Eds.), 1996. Research in Practice. Applied methods for the social sciences. Cape Town: University of Cape Town Press. Sehlapelo, M. \& Terre Blanche, M. Psychometric testing in South Africa: views from above and below. Psychology in Society, 21, 49-59.

Terre Blanche, M. 1998. This is war. Reply to Fred van Staden. South African Journal of Psychology, 28, 44-46.

Thatcher, A. \& Feldman, A. 1998. Cybersex: no mess, no fuss? The search for virtual orgasm. In: M.J. Terre Blanche (Ed.). Touch me I'm sick. Proceedings of the $3^{\text {rd }}$ annual South African Qualitative Methods Conference. Pretoria: University of South Africa.

Todd, PA., McKeen, J.D. \& Gallupe, R.B. 1995. The evolution of IS job skills: a content analysis of IS job advertisements from 1970 to 1990. MIS Quarterly, March, 1-24.

Trollip, A.M. 1991. Die betekenis van die geakkultureerde kledingpraktyke vir bepaalde vroue in 'n Ndyundya-Ndebeleverwantskapgroup [The meaning of acculturated clothing practices for particular women in a Ndyundya-Ndebele kinship group] (1991, D.Phil., Home Economics and Dietetics, University of Pretoria).

Van der Burgh, C. 1984. The social definition of mental illness by medical personnel: a sociological analysis. (Unpublished Doctor of Literature and Philosophy) Pretoria: University of South Africa.

Van Maanen, J. 1988. Tales of the field: On writing ethnography. Chicago: University of Chicago Press.

Van Staden, F. 1998. The 'new discursive paradigm': as yet an elitist European import? Comment on special edition of the SAJP. South African Journal of Psychology, 28, 44. 
Van Vlaenderen, H., \& Gilbert, A. 1993. Participatory research for human capacity building in rural development. In P. Styger, $\&$ M. Cameron (Eds.). Development in the transition. Pretoria: Development Bank of South Africa.

Van Vuuren, R.J. 1991. Dialogue beyond polemics. Pretoria: Human Sciences Research Council.

Van Zyl, C.B. Die gevoelens, ervarings en behoeftes van rasgemengde egpare in die Suid-Afrikaanse konteks - 'n gegronde teorie. Unpublished D.Litt. et. Phil thesis. Johannesburg: Rand Afrikaans University.

Vermeulen, J. 2002. Towards a genetic business code for growth in the transport industry. Unpublished dissertation. Johannesburg: Rand Afrikaans University.

Vermeulen, J., Veldsman, T.H., Roodt, G. \& Schurink, W. 2003. Towards a genetic business code for growth in the transport industry. SA Journal of Human Resource Management, 1 (1), 1-16.

Vogelman, L. Lewis, S., Segal, L. 1994. Life after death row: post traumatic stress and the story of Philip Takedi. South African Journal of Psychology, 24 (2), 91-99.
Vosloo, S. \& Barnard, A. 2002. A qualitative assessment of the development of employee assistance practice in South Africa. South African Journal of Labour Relations, 26 (4), 33-60.

Walker, M. 1994. Research-based staff development. South African Journal of Higher Education, 8, 49-53.

Weick, K.E. 1969. Theory construction as disciplined reflexivity:tradeoffs in the 90's. Academy of Management Review, 24, 797-806.

Welman, J.C. \& Kruger, S.J. 1999. Research methodology for the business and administrative sciences. Cape Town: Oxford University Press Southern Africa.

Wilbraham, L. 1996. "Few of us are potential Miss South Africa's but...": Psychological discourses about women's bodies in advice columns. South African Journal of Psychology, 26, 162-171.

Williams, K., Crafford, A. \& Fourie, L. 2003. An exploration of individual experiences of constant organisational change. $S A$ Journal of Industrial Psychology, 29 (2), 98-105.

Yin, R.K. 1984. Case study research: design and methods. Beverly Hills, CA: Sage. 